\title{
Global Publication Outcomes in Retrograde Intrarenal Surgery and Turkiye's Effectiveness: A Bibliometric Analysis between 1980 and 2019
}

\section{Retrograd Intrarenal Cerrahide Global Yayın Sonuçları ve Türkiye'nin Etkinliği: 1980-2019 Yılları Arasında Bibliyometrik Analiz}

\author{
(D) Mehmet Murat Baykam11, (D) Musa Ekici1, (D) Emre Demir2 \\ ${ }^{1}$ Hitit University Faculty of Medicine, Department of Urology, Çorum, Turkiye \\ 2 Hitit University Faculty of Medicine, Department of Biostatistics, Çorum, Turkiye
}

\begin{abstract}
What's known on the subject? and What does the study add?
Bibliometric analysis on retrograde intrarenal surgery. This study is the first study that makes a holistic analysis of the articles about this issue. One of the notable findings of this study is that Turkiye is among the world countries that produced the highest number of publications about this issue and the hospitals where this technique is used most are located in Turkiye.
\end{abstract}

\begin{abstract}
Objective: Urinary system stone disease is a very common health problem that affects 2 to $3 \%$ of people and causes serious complications when it is not treated. The prevalence of renal stones has been increasing worldwide and surgical methods have changed over time. However, there is no comprehensive bibliometric analysis of the retrograde intrarenal surgery (RIRS) method in the literature. This study aimed to conduct a bibliometric analysis of all articles regarding RIRS published between 1980 and 2019.

Materials and Methods: The literature search was performed using only the following keywords: "RIRS" and "flexible ureterorenoscopy/flexible ureteroscopy", in the "title" part of the search. Using this search method, all the articles published between 1980 and 2019 on this topic were accessed and downloaded from the Web of Science database, and the articles were analyzed using bibliometric methods.

Results: Totally, 1378 publications were found as a result of the literature search, of which 619 were articles. We noted that there has been a rapid increase in the number of publications, especially from the year 2011. Turkiye was found to be the most productive country with regard to RIRS. The journals that contributed most to the literature were: Journal of Endourology, Urology, Journal of Urology, Urolithiasis, and World Journal of Urology.

Conclusion: One of the notable findings of this study is that Turkiye is among the world countries that produced the highest number of publications with regard to this topic and that the hospitals where this technique is used the most are located in Turkiye.
\end{abstract}

Keywords: Retrograde intrarenal surgery, RIRS, Flexible ureterorenoscopy, Bibliometric analysis, Trends

Öz

Amaç: Üriner sistem taş hastalığı, insanların \%2 ila 3'ünü etkileyen ve tedavi edilmediğinde ciddi sorunlara neden olan çok yaygın bir sağlık sorunudur. Renal taşların prevalansı dünya çapında artmaktadır ve cerrahi yöntemler zaman içinde değişmiştir. Bununla birlikte, literatürde retrograd intrarenal cerrahi (RIRC) yönteminin kapsamlı bir bibliyometrik analizi yer almamaktadır. Bu çalışma 1980 ve 2019 yılları arasında yayınlanan RIRC ile ilgili tüm makalelerin bibliyometrik analizini yapmayı amaçlamaktadır.

Gereç ve Yöntem: Literatür taraması sadece aramanın "başlık" kısmında "RIRC" ve "esnek üreterorenoskopi/esnek üreteroskopi" anahtar kelimeleri kullanılarak yapıldı. Bu arama yöntemi kullanılarak 1980-2019 yılları arasında bu konu hakkında yayınlanan tüm makalelere erişildi ve Web of Science veritabanından indirildi. Makaleler bibliometrik yöntemler kullanılarak analiz edildi.

Correspondence: Mehmet Murat Baykam MD, Hitit University Faculty of Medicine, Department of Urology, Çorum, Turkiye Phone: +90 5057516341 E-mail: akekici@gmail.com ORCID-ID: orcid.org/0000-0001-9006-4275

Received: 3.02.2020

Accepted: 17.04.2020

Cite this article as: Baykam MB, Ekici M, Demir E. Global Publication Outcomes in Retrograde Intrarenal Surgery and Turkiye's Effectiveness: A Bibliometric Analysis between 1980 and 2019. J Urol Surg 2020;7(3):184-194

๑Copyright 2020 by the Association of Urological Surgery / Journal of Urological Surgery published by Galenos Publishing House. 
Bulgular: Literatür taraması sonucunda toplam 1378 yayın bulundu. Bu yayınlardan 619'u makaleydi. Özellikle 2011 yılından bu yana yayın sayısında hızlı bir artış olmuştur. Türkiye'nin RIRS konusunda en verimli ülke olduğu tespit edildi. Literatüre en fazla katkıda bulunan dergiler Journal of Endourology, Urology, Journal of Urology, Urolithiasis, and World Journal of Urology olarak bulundu.

Sonuç: Bu çalışmanın dikkate değer bulgularından biri de Türkiye'nin bu konuda en fazla sayıda yayın yapan dünya ülkeleri arasında olması ve bu tekniğin en çok kullanıldığı hastanelerin Türkiye'de bulunmasıdır.

Anahtar Kelimeler: Retrograd intrarenal cerrahi, RIRS, Fleksibıl üreterorenoskopi, Bibliometrik analiz, Trends

\section{Introduction}

Urinary system stone disease encompasses the kidneys, ureter, bladder, and urethral calculus. It is a commonly encountered health problem affecting 2-3\% of people and causes serious complications when it is not treated. The retrograde intrarenal surgery (RIRS) technique performed under general anesthesia is done using a thin instrument, $3 \mathrm{~mm}$ in diameter (flexible renoscopy), with a light source that enables monitoring with an optic fiber by passing from the urethra (urinary canal) and bladder (urinary bladder) to the path that connects kidneys and bladder (ureter), in order to break the stone located within the kidney. Renal stone is broken using a laser power source that can pass through renoscopy and the big stone parts are taken out after the breaking procedure; the fragments that are now in powdered form are removed from the kidney $(1,2)$.

Today, RIRS enables the successful treatment for most small or medium size renal stones, without any need for open surgery or percutaneous nephrolithotomy (PCNL). This method makes it possible to access the kidney from the abdominal wall without needing to open any holes; renoscopy that could be bent by entering from the urinary canal and laser enable the complete breaking and removal of the stones. Using this method, patients could be discharged from the hospital in a shorter period and begin to live as before (3-5).

The treatment of renal stones has recently undergone significant changes. The treatment options include open surgery, as well as the less invasive PCNL, extracorporeal shock wave lithotripsy (ESWL), and RIRS (6). With the increase in surgical experience, RIRS has become an important and acceptable treatment option for renal stones for all age groups, stone sizes, and localizations (7).

Bibliometric analyses enabled the identification of the most effective and top-cited studies and journals, through the statistical analysis of articles published with regard to a specific topic, specific research field, journal, or a country (8-11). They also enabled us to explore the collaborations between countries, authors, and institutions.

Bibliometric studies involve the investigation of the relationship between publication productivity and various factors possible (12-15). There have been several bibliometric studies in the medical field in recent years. The value of bibliometric studies has been increasing as a result of the increased number of publications in literature day by day (16).

The prevalence of renal stones has been increasing worldwide $(5,17)$, and surgical methods have changed over time. However, there is no comprehensive bibliometric analysis of this method in the literature This study aimed to conduct a bibliometric analysis of all the articles regarding RIRS published between 1980 and 2019.

\section{Material and Methods}

The literature review was done using the following keywords: "RIRS" and "flexible ureterorenoscopy/flexible ureteroscopy/ FURS), in the "title" part of the search. [Access codes: (title: (retrograde intrarenal*) or title: (flexible uretero*) or title: (RIRS) or title: (FURS) timespan: 1980-2019. indexes: SCl-Expanded, ACtHCl, SSCl, CPCl-S, BKCl-S, CPCl-SSH, BKCl-SSH, ESCl) and access date: August 01, 2020]. Through this search, all the articles that were published between 1980 and 2019 on this topic were accessed and downloaded from the Web of Science (WoS) database. The articles were analyzed using bibliometric methods. VOSviewer (Version 1.6.13) package program was used for the bibliometric web visualizations. The world map was drawn using an online web site (http://lert.co.nz/map/).

\section{Results}

Totally, 1378 publications were found as a result of the literature search, of which 619 were articles, 544 were Meeting Abstracts, 109 were Editorial Materials, 53 were Reviews, 33 were Letters, 19 were Proceedings Papers, and 20 were other publications (Early Access, Correction, Book Chapter, Note). This study included the bibliometric analysis of 619 publications only; all of which were articles. Of these articles, 90.3\% were English $(n=559)$, and the others were French $(n=34)$, Spanish $(n=22)$, Turkish ( $n=3)$, and Korean $(n=1)$.

The 619 articles accessed received 8518 citations (without self-citations 5549) in total, and the mean citation number per article was found to be 13,76 , while the $\mathrm{H}$-index of all the articles was 44. 


\section{Active Research Areas}

The top 10 research areas of the published articles included Urology and Nephrology (515: 83.2\%); General Internal medicine (35); Surgery (30); Experimental Medicine Research (25); Multidisciplinary Sciences (11); Pediatrics (10); Pharmacology and Pharmacy (4); Radiology, Nuclear Medicine, and Medical Imaging (3); Anatomy Morphology (2); and Biotechnology Applied Microbiology (2).

\section{Development of Publications}

The distribution of the articles is demonstrated in Figure 1. The increase in the number of articles has been significant since 2011, and a notable increase was found after the year 2014.

\section{Active Countries}

A total of 51 countries had made publications on this topic; Figure 2 demonstrates the rank order of 23 countries that produced the highest number of articles. The network map of international collaborations between the 30 countries that produced a minimum of three publications is displayed in Figure 3.

\section{Active Authors}

Table 1 presents the top 25 authors producing the highest number of publications about this issue.

\section{Active Organizations}

The top active organizations involved and organizations that produced the highest number of publications are demonstrated in Table 2.

\section{Active Journals and Citation Analysis}

Table 3 presents the active journals producing the highest number of publications regarding this topic. The number of citations and the number of citations per article are shown in the last column of Table 3. The Citation network visualization map among the journals is given in Figure 4.

\section{Most Cited Articles}

Table 4 displays the top 15 articles that had received the highest number of citations (18-32).

\section{Co-citation Analysis}

A total of 4484 publications were cited in the references section of the 619 published articles. The studies receiving the highest number of citations were those conducted by Dindo, 2004 (Citation: 88) (33); Breda, 2009 (Citation: 80) (21); Breda, 2008 (Citation: 69) (20); Traxer, 2013 (Citation: 65) (18); and Bozkurt, 2011 (Citation: 58) (25). There were 33 articles that received citations at least 30 times. The density map of these articles is shown in Figure 5.

\section{Trend Topics}

There were 697 different keywords in the 619 articles. Figure 6 shows the network map of the cluster analysis results conducted with 71 keywords that were used in minimum of four different articles. The network map of trend words analysis is given in Figure 7.

\section{Discussion}

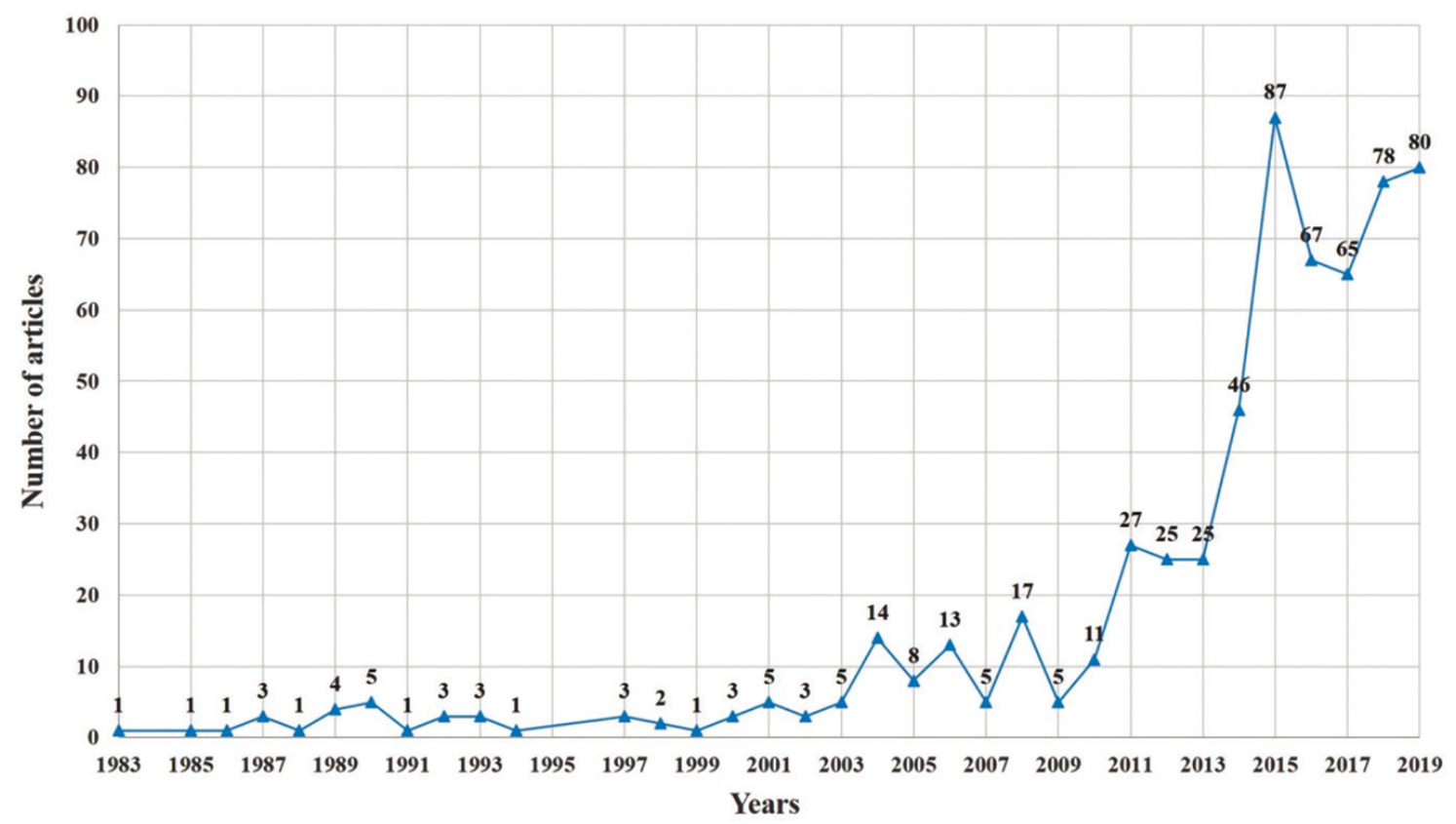

Figure 1. Distribution of articles published on retrograde intrarenal surgery by years 


\begin{tabular}{|l|l|l|}
\hline \multicolumn{3}{|l|}{ Table 1. Active authors on retrograde intrarenal surgery } \\
\hline Authors & RC & $\%$ \\
\hline Traxer & 46 & 7.431 \\
\hline Resorlu & 23 & 3.716 \\
\hline Unsal & 20 & 3.231 \\
\hline Atis & 15 & 2.423 \\
\hline Bagley & 15 & 2.423 \\
\hline Binbay & 15 & 2.423 \\
\hline Bozkurt & 15 & 2.423 \\
\hline Caskurlu & 15 & 2.423 \\
\hline Proietti & 15 & 2.423 \\
\hline Giusti & 13 & 2.100 \\
\hline Ozgor & 13 & 2.100 \\
\hline Tepeler & 12 & 1.939 \\
\hline Doizi & 11 & 1.777 \\
\hline Matsuzaki & 11 & 1.777 \\
\hline Monga & 11 & 1.777 \\
\hline Muslumanoglu & 11 & 1.777 \\
\hline Lechevallier & 10 & 1.616 \\
\hline Sener & 10 & 1.616 \\
\hline Yao & 10 & 1.616 \\
\hline Zeng & 10 & 1.616 \\
\hline Cho & 9 & 1.454 \\
\hline Clayman & 9 & 1.454 \\
\hline Ito & 9 & 1.454 \\
\hline Ozyuvali & 9 & 1.454 \\
\hline Preminger & 9 & 1.454 \\
\hline RC: Record count C: Number of citation & & \\
\hline & & \\
\hline & & \\
\hline
\end{tabular}

In line with the increase in the importance of RIRS, the importance of the number of publications and citations has also increased. Particularly, the number of publications has increased rapidly since 2011, and it has reached approximately 80 articles in recent years. Turkiye was found to be the most productive country with regards to RIRS. Although the publication productivity of developed countries such as the USA, China, France, United Kingdom, Germany, Italy, Spain, and Japan reveals that publication productivity is closely related to financial power; it is also important to note the contribution of countries such as Turkiye, India, Brazil, Chili, and Romania.

The analysis performed to detect the collaboration between the countries showed that the collaborations were in clusters of geographical location. Developing or undeveloped countries could be encouraged to create collaborations on this issue topic.

The journals that had the highest contribution to the literature were Journal of Endourology, Urology, Journal of Urology, Urolithiasis, and World Journal of Urology. As per the total number of citations, the Journal of Endourology, Urology,

\begin{tabular}{|c|c|c|c|c|c|}
\hline $\begin{array}{l}\text { Organizations- } \\
\text { enhanced }\end{array}$ & RC & $\%$ & Organizations & RC & $\%$ \\
\hline Sorbonne Universite & 47 & 7.593 & University Paris 06 & 17 & 2.746 \\
\hline $\begin{array}{l}\text { Assistance Publique } \\
\text { Hopitaux Paris Aphp }\end{array}$ & 46 & 7.431 & $\begin{array}{l}\text { Guangzhou Med } \\
\text { University }\end{array}$ & 16 & 2.585 \\
\hline $\begin{array}{l}\text { Hopital Universitaire } \\
\text { Tenon Aphp }\end{array}$ & 45 & 7.270 & $\begin{array}{l}\text { Kecioren Training } \\
\text { Res Hospital }\end{array}$ & 16 & 2.585 \\
\hline $\begin{array}{l}\text { Ankara Kecioren } \\
\text { Training Research } \\
\text { Hospital }\end{array}$ & 23 & 3.716 & Hop Tenon & 15 & 2.423 \\
\hline $\begin{array}{l}\text { Diskapi Yildirim } \\
\text { Beyazit Training } \\
\text { Research Hospital }\end{array}$ & 21 & 3.393 & $\begin{array}{l}\text { Thomas Jefferson } \\
\text { University }\end{array}$ & 15 & 2.423 \\
\hline $\begin{array}{l}\text { Istanbul Medeniyet } \\
\text { University }\end{array}$ & 19 & 3.069 & Gazi University & 14 & 2.262 \\
\hline $\begin{array}{l}\text { Istanbul Haseki } \\
\text { Training Research } \\
\text { Hospital } \\
\end{array}$ & 17 & 2.746 & $\begin{array}{l}\text { Istanbul Medeniyet } \\
\text { University }\end{array}$ & 12 & 1.939 \\
\hline $\begin{array}{l}\text { Guangzhou Medical } \\
\text { University }\end{array}$ & 16 & 2.585 & $\begin{array}{l}\text { Bezmialem Vakif } \\
\text { University }\end{array}$ & 11 & 1.777 \\
\hline Jefferson University & 15 & 2.423 & Bozok University & 11 & 1.777 \\
\hline Gazi University & 14 & 2.262 & $\begin{array}{l}\text { Yokohama City } \\
\text { University }\end{array}$ & 11 & 1.777 \\
\hline $\begin{array}{l}\text { University of } \\
\text { California System }\end{array}$ & 13 & 2.100 & $\begin{array}{l}\text { Ankara Numune } \\
\text { Training Res } \\
\text { Hospital }\end{array}$ & 10 & 1.616 \\
\hline $\begin{array}{l}\text { Ankara Numune } \\
\text { Training Research } \\
\text { Hospital }\end{array}$ & 12 & 1.939 & Duke University & 10 & 1.616 \\
\hline $\begin{array}{l}\text { Bezmialem Vakif } \\
\text { University }\end{array}$ & 12 & 1.939 & $\begin{array}{l}\text { Haseki Training Res } \\
\text { Hospital }\end{array}$ & 10 & 1.616 \\
\hline $\begin{array}{l}\text { Istanbul Goztepe } \\
\text { Training and Research } \\
\text { Hospital }\end{array}$ & 12 & 1.939 & $\begin{array}{l}\text { University Health } \\
\text { Science }\end{array}$ & 10 & 1.616 \\
\hline $\begin{array}{l}\text { Seoul National } \\
\text { University Snu }\end{array}$ & 12 & 1.939 & $\begin{array}{l}\text { University } \\
\text { Wisconsin }\end{array}$ & 10 & 1.616 \\
\hline \begin{tabular}{|l|} 
Vita Salute San \\
Raffaele University
\end{tabular} & 12 & 1.939 & $\begin{array}{l}\text { Washington } \\
\text { University }\end{array}$ & 9 & 1.454 \\
\hline Bozok University & 11 & 1.777 & Ankara University & 8 & 1.292 \\
\hline $\begin{array}{l}\text { Ministry of Health } \\
\text { Turkiye }\end{array}$ & 11 & 1.777 & $\begin{array}{l}\text { Capital Med } \\
\text { University }\end{array}$ & 8 & 1.292 \\
\hline $\begin{array}{l}\text { Yokohama City } \\
\text { University }\end{array}$ & 11 & 1.777 & $\begin{array}{l}\text { Seoul Natl } \\
\text { University }\end{array}$ & 8 & 1.292 \\
\hline \begin{tabular}{|l|} 
Aix Marseille \\
Universite
\end{tabular} & 10 & 1.616 & University Tubingen & 8 & 1.292 \\
\hline Duke University & 10 & 1.616 & $\begin{array}{l}\text { Asklepios Hospital } \\
\text { Barmbek }\end{array}$ & 7 & 1.131 \\
\hline $\begin{array}{l}\text { Seoul National } \\
\text { University Hospital }\end{array}$ & 10 & 1.616 & Cent S University & 7 & 1.131 \\
\hline $\begin{array}{l}\text { University of } \\
\text { Wisconsin Madison }\end{array}$ & 10 & 1.616 & $\begin{array}{l}\text { Huazhong } \\
\text { University Sci } \\
\text { Technol }\end{array}$ & 7 & 1.131 \\
\hline \begin{tabular}{|l|} 
University of \\
Wisconsin System
\end{tabular} & 10 & 1.616 & Karabuk University & 7 & 1.131 \\
\hline $\begin{array}{l}\text { Eberhard Karls } \\
\text { University of } \\
\text { Tubingen }\end{array}$ & 9 & 1.454 & $\begin{array}{l}\text { Medeniyet } \\
\text { University }\end{array}$ & 7 & 1.131 \\
\hline \multicolumn{6}{|c|}{ RC: Record count C: Number of citation } \\
\hline
\end{tabular}


Journal of Urology, and BJU International were the effective journals. The journals receiving the highest number of citations per article were European Urology, Journal of Urology, BJU International, Urology, and Urological Research. Researchers could be recommended to consider these journals for studies that they would like to receive more citations. As for the journals addressing Turkiye, the notable journals were the Journal of Urological Surgery and Turkish Journal of Urology.

The articles with the highest total number of citations included the articles entitled "Prospective Evaluation and Classification of Ureteral Wall Injuries Resulting from Insertion of a Ureteral
Access Sheath During RIRS" written by Traxer and Thomas (18) and "Ureteral access sheath provides protection against elevated renal pressures during routine flexible ureteroscopic stone manipulation" written by Auge et al. (19). Apart from these studies, the top-cited articles according to the average number of citations included the studies entitled "Flexible Ureteroscopy and Laser Lithotripsy for Multiple Unilateral Intrarenal Stones" and "Flexible ureteroscopy and laser lithotripsy for single intrarenal stones $2 \mathrm{~cm}$ or greater - Is this the new frontier?" by Breda $(20,21)$, respectively. The top-cited Turkish study entitled "RIRS Versus Percutaneous Nephrolithotomy in the Management

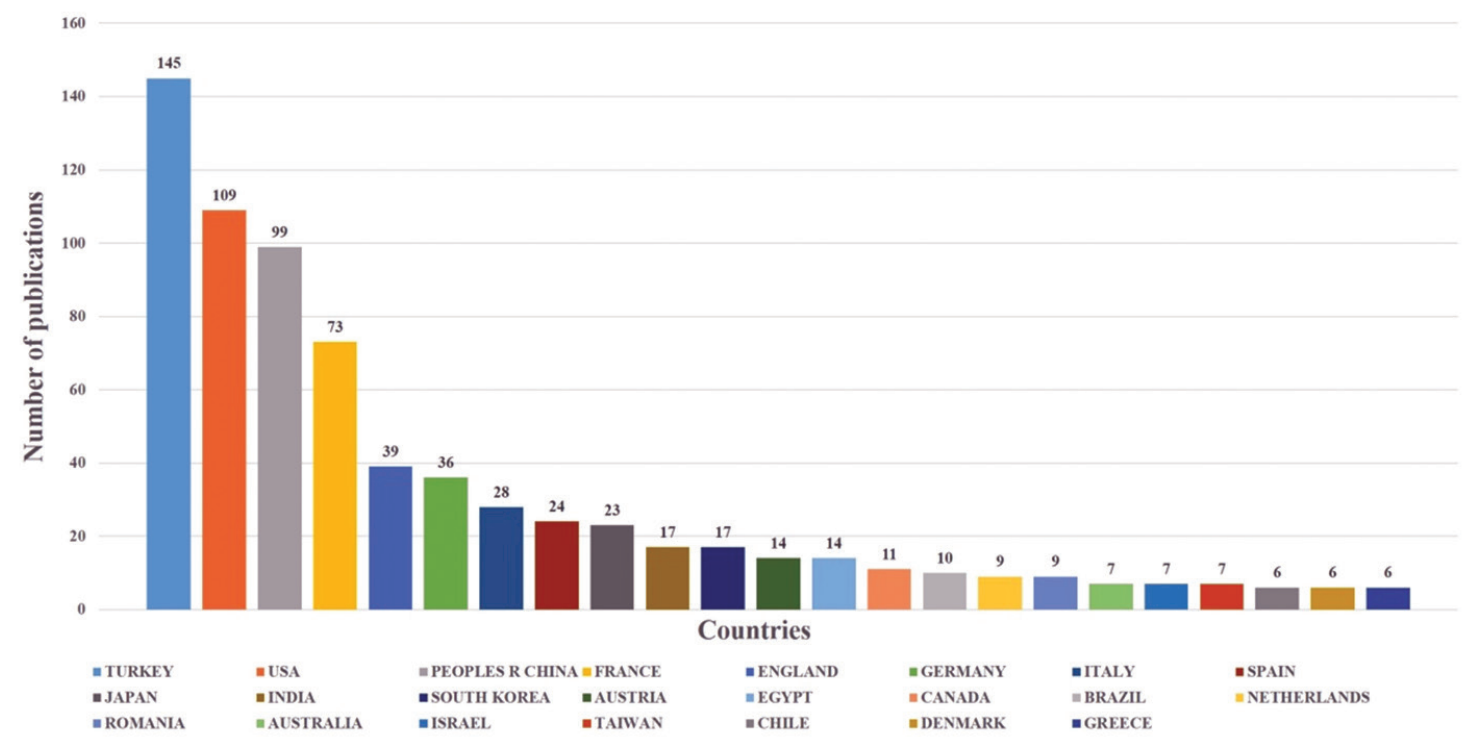

Figure 2. World map on the distribution of world countries producing publications on retrograde intrarenal surgery

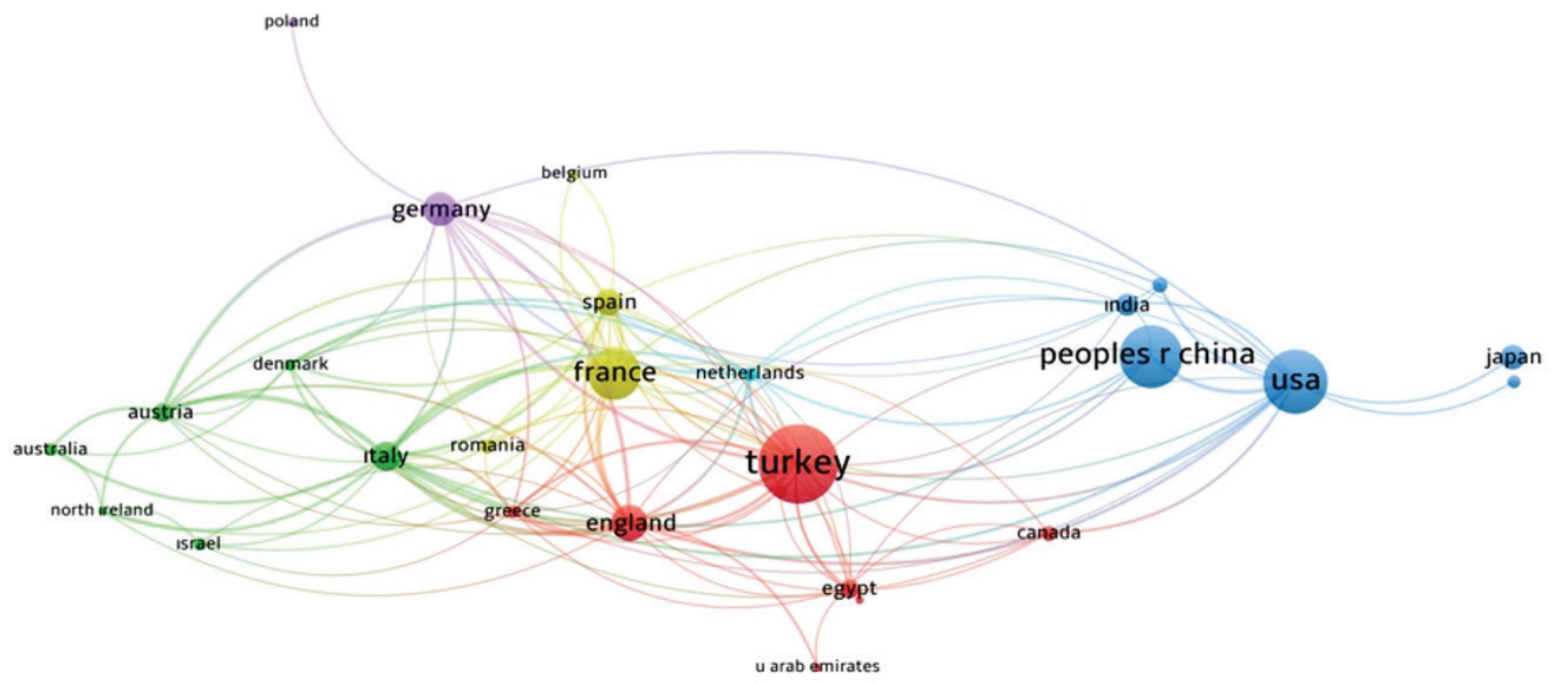

VOSviewer

Figure 3. Network visualization map showing the international collaboration of countries on retrograde intrarenal surgery Footnote: Colors indicate clustering 


\begin{tabular}{|c|c|c|c|c|}
\hline Journals & RC & $\%$ & c & AC \\
\hline Journal of Endourology & 114 & 18.417 & 2195 & 19.3 \\
\hline Urology & 49 & 7.916 & 1213 & 24.8 \\
\hline Journal of Urology & 37 & 5.977 & 1789 & 48.4 \\
\hline Urolithiasis & 34 & 5.493 & 426 & 12.5 \\
\hline World Journal of Urology & 34 & 5.493 & 445 & 13.1 \\
\hline Progres En Urologie & 33 & 5.331 & 126 & 3.8 \\
\hline Urologia Internationalis & 21 & 3.393 & 171 & 8.1 \\
\hline BJU International & 19 & 3.069 & 548 & 28.8 \\
\hline Urology Journal & 19 & 3.069 & 73 & 3.8 \\
\hline Actas Urologicas Espanolas & 13 & 2.100 & 78 & 6.0 \\
\hline International Braz J Urol & 13 & 2.100 & 77 & 5.9 \\
\hline International Journal of Clinical and Experimental Medicine & 13 & 2.100 & 38 & 2.9 \\
\hline Archivos Espanoles De Urologia & 10 & 1.616 & 7 & 0.7 \\
\hline Turkish Journal of Urology & 9 & 1.454 & 24 & 2.7 \\
\hline Journal of Pediatric Urology & 8 & 1.292 & 19 & 2.4 \\
\hline Arab Journal of Urology & 7 & 1.131 & 11 & 1.6 \\
\hline BMC Urology & 7 & 1.131 & 17 & 2.4 \\
\hline Urological Research & 7 & 1.131 & 168 & 24.0 \\
\hline Archivio Italiano Di Urologia E Andrologia & 6 & 0.969 & 20 & 3.3 \\
\hline CUAJ Canadian Urological Association Journal & 6 & 0.969 & 37 & 6.2 \\
\hline European Urology & 6 & 0.969 & 364 & 60.7 \\
\hline International Urology and Nephrology & 6 & 0.969 & 34 & 5.7 \\
\hline Central European Journal of Urology & 5 & 0.808 & 34 & 6.8 \\
\hline International Journal of Urology & 5 & 0.808 & 78 & 15.6 \\
\hline Journal of Urological Surgery & 5 & 0.808 & 0 & 0.0 \\
\hline
\end{tabular}

of Lower-Pole Renal Stones with a Diameter of 15 to $20 \mathrm{~mm}$ was written by Bozkurt et al. (25) in the Journal of Endourology.

According to the co-citation analysis results, the studies conducted by Dindo et al. (33), Breda et al. $(20,21)$, Traxer et al. (18), and Bozkurt et al. (25) were cited the most in the references sections of the articles. Researchers interested in RIRS are recommended to first read these studies.

Keyword analyses indicated eight different clusters, and the cluster centers included RIRS, flexible ureteroscopy, ureteroscopy, and urolithiasis. While previous percutaneous nephrolithotomy and ureteroscopy topics were searched, especially after the year 2000, laser and RIRS topics were searched, which is considered to be as a result of using holmium laser in RIRS operations in 1995.

\section{Study Limitation}

The limitation of the present study is that it did not search the PubMed and Scopus databases. WoS database was preferred, as the journals with a high impact factor are indexed there and it is a more reliable database in terms of citations $(11,34,35)$.

\section{Conclusion}

With the increase of the importance of RIRS, a less invasive technique for the treatment of urinary system stone diseases, the present study is the first of its kind study to conduct a holistic analysis of the articles on this issue. The study is believed to guide physicians, academics, and students in studying RIRS, on topics such as effective journals, top-cited studies, trend topics, and the most productive countries. One of the notable findings of this study is that Turkiye is among the world countries that had the highest number of publications on this topic and the hospitals where this technique is used are mostly located in Turkiye.

\section{Ethics}

Ethics Committee Approval: This article does not contain any studies with human participants or animals performed by any of the authors. 


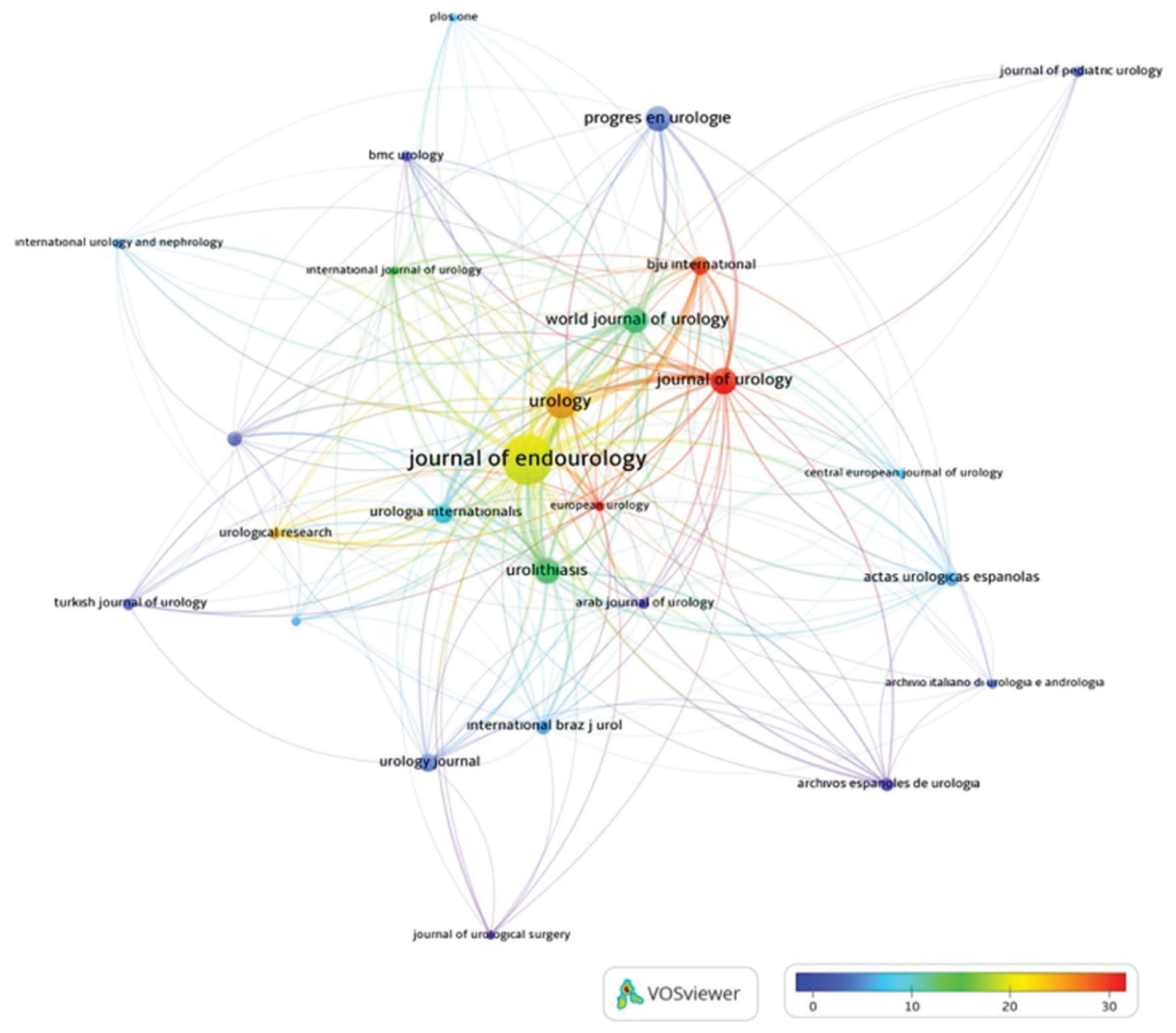

Figure 4. Network visualization map of citation analysis of active journals producing publications on retrograde intrarenal surgery Footnote: Number of receiving citations increases from blue to red 


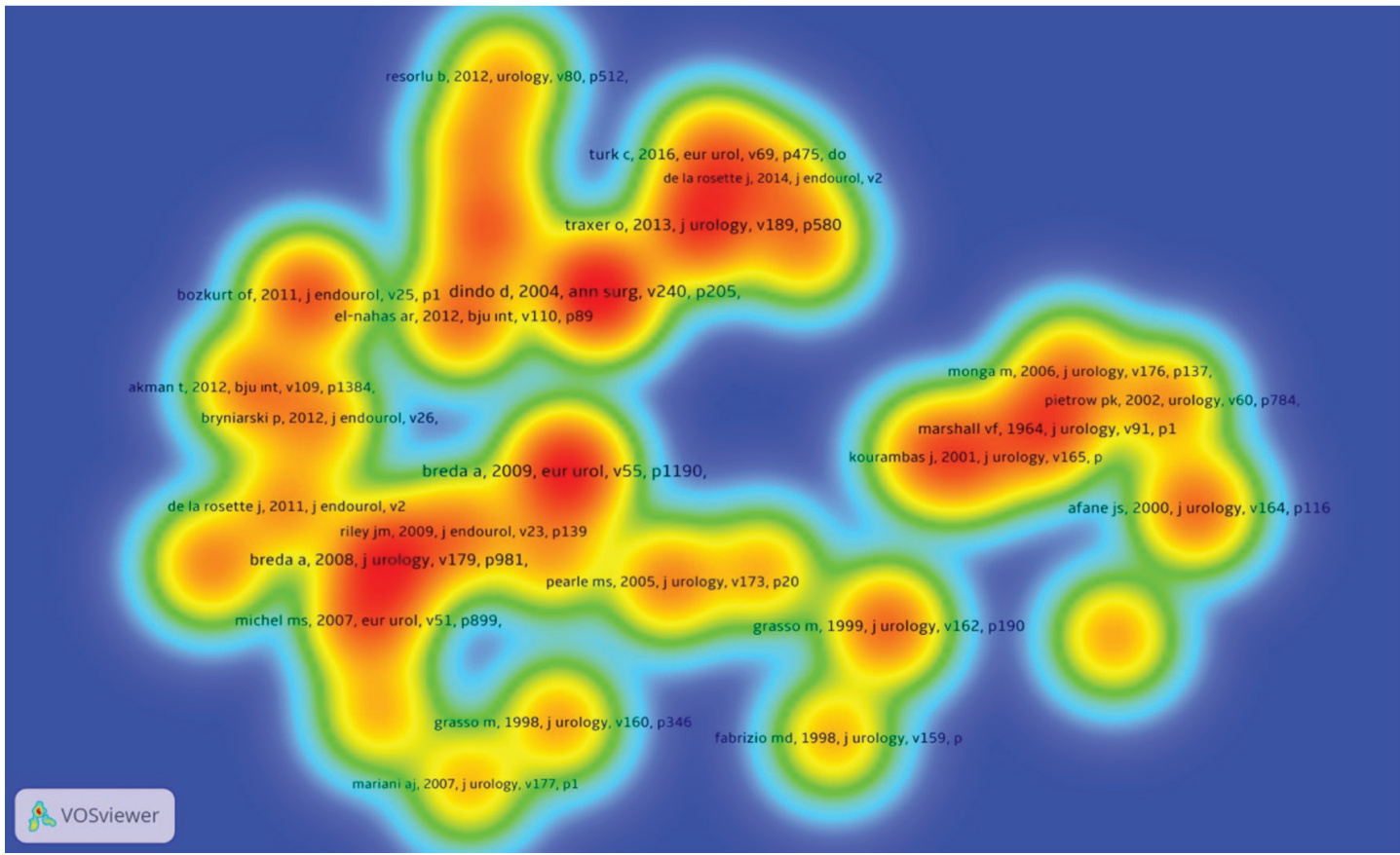

Figure 5. Density map of co-citation analysis in references on retrograde intrarenal surgery

Footnote: Number of receiving citations increases from blue to red

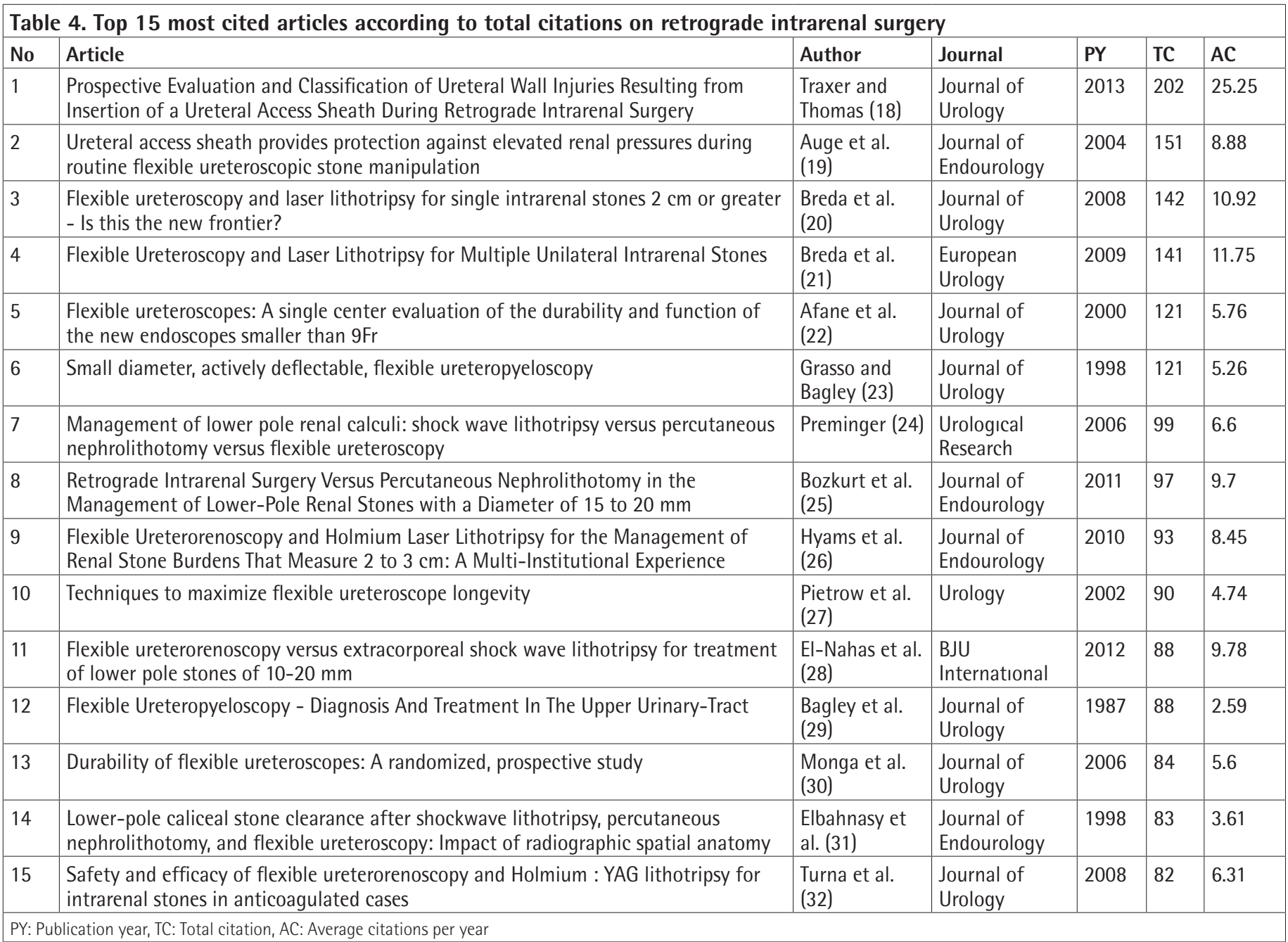




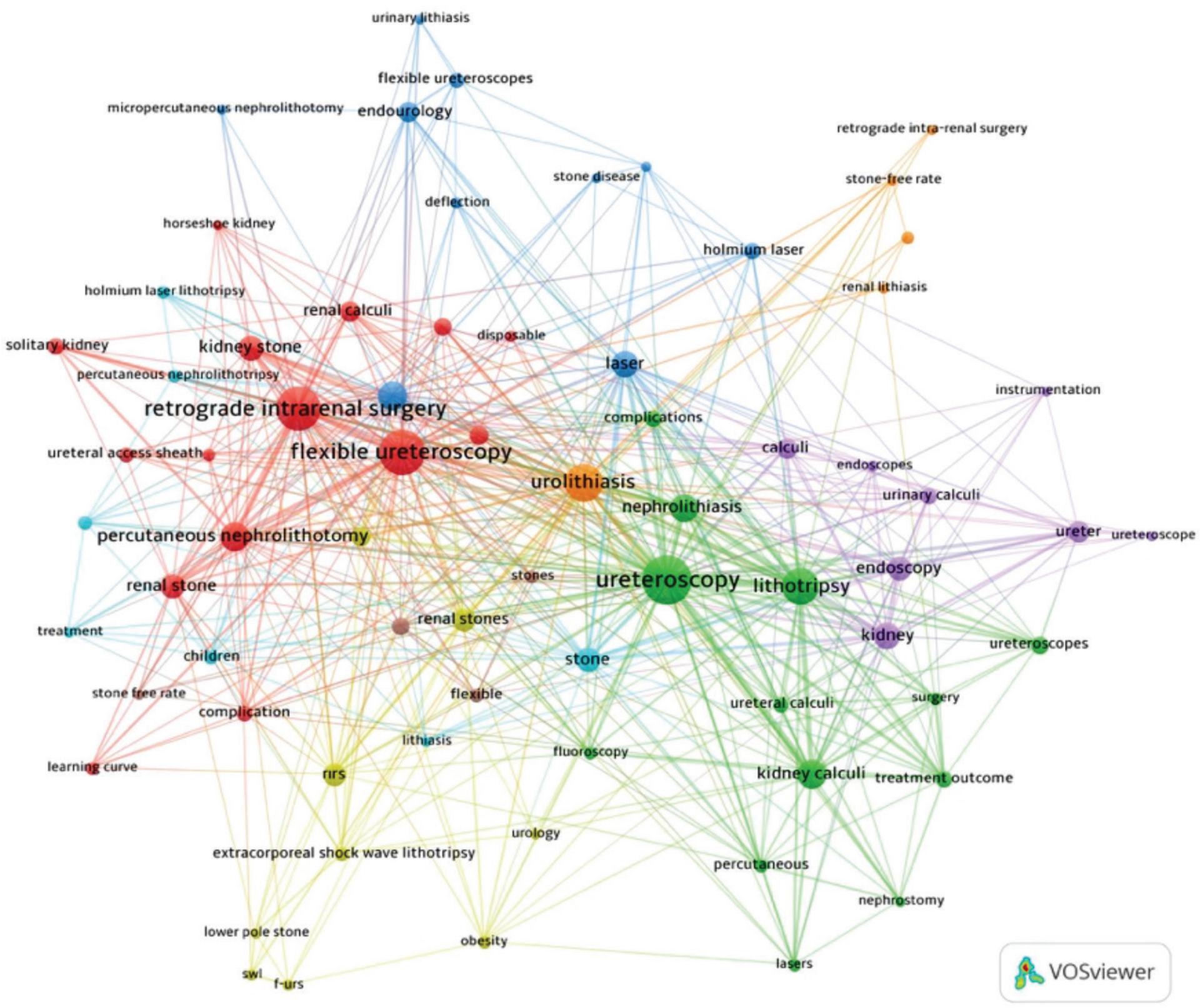

Figure 6. Network visualization map showing cluster analysis results based on keyword analysis on retrograde intrarenal surgery Footnote: Colors indicate clustering 


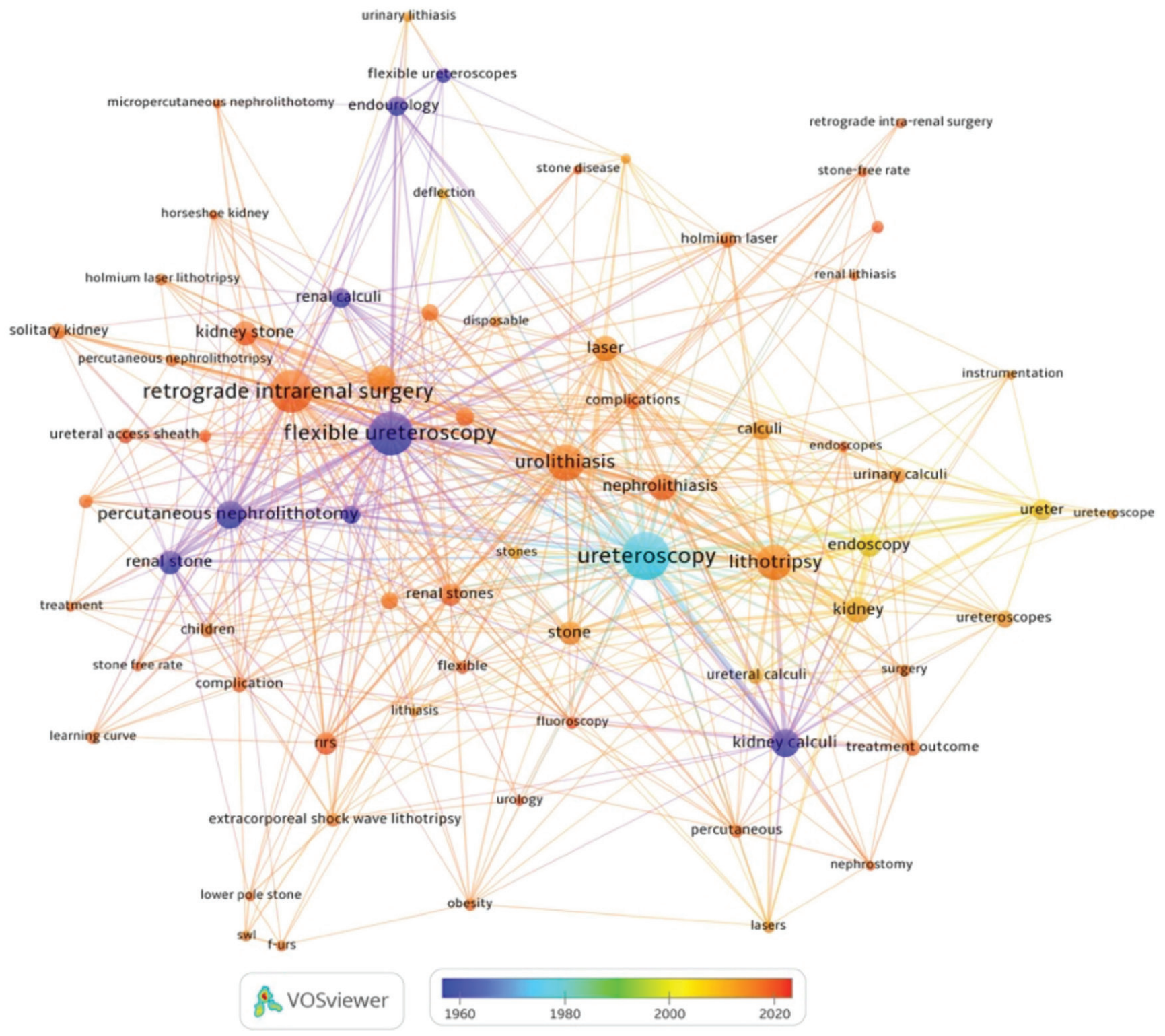

Figure 7. Network visualization map showing current trends based on keyword analysis results on retrograde intrarenal surgery Footnote: Updates increases from blue to red

Informed Consent: For this type of study formal consent is not required.

Peer-review: Externally peer-reviewed.

\section{Authorship Contributions}

Concept: M.M.B., M.E., Design: M.M.B., M.E., Data Collection or Processing: M.E., E.D., Analysis or Interpretation: M.E., E.D., Literature Search: M.E., E.D., Writing: M.M.B., M.E.
Conflict of Interest: No conflict of interest was declared by the authors.

Financial Disclosure: The authors declared that this study received no financial support. 


\section{References}

1. Oztekin U, Caniklioglu M, Selmi V, Kantekin, CU, Atac, F, Gurel, A, Sari S. Do Anesthesia Methods in Retrograde Intrarenal Surgery Make Difference Regarding the Success of Ureteral Access and Surgical Outcomes? Journal of Laparoendoscopic \&t Advanced Surgical Techniques 2020;30:273-277.

2. Lee MH, Lee IJ, Kim TJ, Lee SC, Jeong CW, Hong SK, Oh JJ. The Effect of Short-term Preoperative Ureteral Stenting on the Outcomes of Retrograde Intrarenal Surgery for Renal Stones. World Journal of Urology 2019;37:14351440.

3. De S, Autorino R, Kim FJ, Zargar H, Laydner H, Balsamo R, De Sio M. Percutaneous nephrolithotomy versus retrograde intrarenal surgery: a systematic review and meta-analysis. European Urology 2015:67;125-137.

4. Srisubat A, Potisat S, Lojanapiwat B, Setthawong V, Laopaiboon M. Extracorporeal shock wave lithotripsy (ESWL) versus percutaneous nephrolithotomy (PCNL) or retrograde intrarenal surgery (RIRS) for kidney stones. Cochrane Database of Systematic Reviews 2014:11. Art. No.: CD007044.

5. Salvadó JA, Olivares R, Cabello JM, Cabello R, Moreno S, Pfeifer J, Velasco A. Retrograde intrarenal surgery using the single-use flexible ureteroscope Uscope 3022 (Pusen ${ }^{\mathrm{T} M}$ ): evaluation of clinical results. Central European Journal of Urology 2018;71:202-207.

6. Güzelburç V, Erkurt B. Retrograd Intrarenal Cerrahi: Teknik, Endikasyonlar ve Komplikasyonları. Turkiye Klinikleri Urology-Special Topics 2016:9;55-61.

7. Alan C. Koçoğlu H. Ersay AR. Retrograde iıntrarenal surgery: technic, clinical results, tips and tricks. The New Journal of Urology 2011;6:32-41.

8. Demir E. The evolution of spirituality, religion and health publications: Yesterday, today and tomorrow. J Relig Health 2019:58;1-13.

9. Doğan G. Kayır S. Global Scientific Outputs of Brain Death Publications and Evaluation According to the Religions of Countries, J Relig Health 2020:59:96-112.

10. Demir E, Comba A. The Evolution of Celiac Disease Publications: A Holistic Approach with Bibliometric Analysis. Ir J Med Sci 2019;189:267-276.

11. Demir $E_{1}$ Yaşar $E_{1}$ Özkoçak V, Yıldırım E. The evolution of the field of legal medicine: A holistic investigation of global outputs with bibliometric analysis. J Forensic Leg Med 2020:69;101885.

12. Doğan G, İpek H. The Development of Necrotizing Enterocolitis Publications: A Holistic Evolution of Global Literature with Bibliometric Analysis. Eur J Pediatr Surg 2020;30:293-303.

13. Ozsoy Z, Demir E. The Evolution of Bariatric Surgery Publications and Global Productivity: A Bibliometric Analysis. Obesity Surgery 2018:28:1117-1129.

14. Ozsoy Z, Demir E. Which Bariatric Procedure Is the Most Popular in the World? A Bibliometric Comparison, Obesity Surgery 2018:28;2339-2352.

15. Yıldırım $E$, Demir E. Comparative bibliometric analysis of fertility preservation. Annals of Medical Research 2019:26:1622-1628.

16. Muslu Ü. The evolution of breast reduction publications: a bibliometric analysis. Aesthetic Plastic Surgery 2018:42;679-691.

17. Heers $H_{1}$ Turney BW. Trends in urological stone disease: a 5-year update of hospital episode statistics. BJU Int 2016;118:785-789.

18. Traxer 0 , Thomas A. Prospective evaluation and classification of ureteral wall injuries resulting from insertion of a ureteral access sheath during retrograde intrarenal surgery. The Journal of Urology 2013:189;580-584.

19. Auge BK, Pietrow PK, Lallas CD, Raj GV, Santa-Cruz, RW, Preminger GM. Ureteral access sheath provides protection against elevated renal pressures during routine flexible ureteroscopic stone manipulation. Journal of Endourology 2004:18;33-36.

20. Breda A, Ogunyemi O, Leppert JT, Lam JS, Schulam PG. Flexible ureteroscopy and laser lithotripsy for single intrarenal stones $2 \mathrm{~cm}$ or greater-is this the new frontier? The Journal of Urology 2008:179;981-984.

21. Breda A, Ogunyemi O, Leppert JT, Schulam PG. Flexible ureteroscopy and laser lithotripsy for multiple unilateral intrarenal stones. European Urology 2009:55;1190-1197.

22. Afane JS, Olweny EO, Bercowsky E, Sundaram CP, Dunn MD, Shalhav AL, McDougall EM, Clayman RV Flexible ureteroscopes: a single center evaluation of the durability and function of the new endoscopes smaller than 9Fr. The Journal of Urology 2000:164;1164-1168.

23. Grasso M, Bagley D. Small diameter, actively deflectable, flexible ureteropyeloscopy. The Journal of Urology 1998:160;1648-1654.

24. Preminger GM. Management of lower pole renal calculi: shock wave lithotripsy versus percutaneous nephrolithotomy versus flexible ureteroscopy. Urological Research 2006:34;108-111.

25. Bozkurt OF, Resorlu B, Yildiz Y, Can CE, Unsal A. Retrograde intrarenal surgery versus percutaneous nephrolithotomy in the management of lowerpole renal stones with a diameter of 15 to $20 \mathrm{~mm}$. Journal of Endourology 2011:25;1131-1135.

26. Hyams ES, Munver R, Bird VG, Uberoi J, Shah O. Flexible ureterorenoscopy and holmium laser lithotripsy for the management of renal stone burdens that measure 2 to $3 \mathrm{~cm}$ : a multi-institutional experience. Journal of Endourology 2010:24;1583-1588.

27. Pietrow $P K$, Auge BK, Delvecchio FC, Silverstein AD, Weizer AZ, Albala DM, Preminger GM. Techniques to maximize flexible ureteroscope longevity. Urology 2002:60;784-788.

28. El-Nahas AR, Ibrahim HM, Youssef RF, Sheir KZ. Flexible ureterorenoscopy versus extracorporeal shock wave lithotripsy for treatment of lower pole stones of 10-20 mm. BJU International 2012:110;898-902.

29. Bagley DH, Huffman JL, Lyon ES. Flexible ureteropyeloscopy: diagnosis and treatment in the upper urinary tract. The Journal of Urology 1987:138;280285.

30. Monga $M$, Best $S$, Venkatesh $R$, Ames $C$, Lee $C$, Kuskowski $M$, Schwartz $S$, Vanlangendock $R$, Skenazy J, Landman J. Durability of flexible ureteroscopes: a randomized, prospective study. The Journal of Urology 2006:176;137-141.

31. Elbahnasy AM, Clayman RV, Shalhav AL, Hoenig DM, Chandhoke P, Lingeman JE, Denstedt JD, Kahn R, Assimos DG, Nakada SY. Lower-pole caliceal stone clearance after shockwave lithotripsy, percutaneous nephrolithotomy, and flexible ureteroscopy: impact of radiographic spatial anatomy. Journal of Endourology 1998:12;113-119.

32. Turna B, Stein RJ, Smaldone MC, Santos BR, Kefer JC, Jackman SV, Averch TD, Desai MM. Safety and efficacy of flexible ureterorenoscopy and holmium: YAG lithotripsy for intrarenal stones in anticoagulated cases. The Journal of Urology 2008:179;1415-1419.

33. Dindo D, Demartines N, Clavien PA. Classification of surgical complications: a new proposal with evaluation in a cohort of 6336 patients and results of a survey. Annals of Surgery 2004:240;205.

34. Kiraz M, Demir E. A bibliometric analysis of publications on spinal cord injury during 1980-2018. World Neurosurgery. 2020:136;504-513.

35. Doğan, G. The Effect of Religious Beliefs on the Publication Productivity of Countries in Circumcision: A Comprehensive Bibliometric View. Journal of Religion and Health 2020:59;1126-1136. 